\title{
PEMIMPIN MADRASAH DALAM PERSPEKTIF AL-QUR'AN HADITS
}

\author{
Nurul Yaqien \\ nyaqien@gmail.com \\ Jurusan MPI FITK UIN Maulana Malik Ibrahim Malang \\ Jawa Timur, Indonesia
}

\begin{abstract}
There are various requirements in becoming the leader of madrasah in Islam, such as the existence of justice, honesty, resposibility, emphaty, and so fort, which are pertinent to the expert theories about leadership. It is preferrable that the leader of madrasah come from generous generation because, indirectly, it affects the leadership quality of the leader. Once a person become a leader in madrasah, he must be able to perform very well because it means that he deal with responsibility in the world and in the hereafter. Rasulullah saw. saw forbade people to ask to be a leader, especially when they do not own most leadership aspects. If people insist for that responsibility, Allah swt might will not bless that job, and futhermore, there might be bad things happen in the future, such as students' failure in national examination, lack of school achievement, lack of society reliance, and so forth. These might be happen since basically, Allah swt will not help people who ask for position.
\end{abstract}

Key words:leader, madrasah, Alquran, Hadits

\section{Abstrak}

Ada berbagai persyaratan untuk menjadi pemimpin madrasah dalam Islam, seperti adanya keadilan, kejujuran, tanggung jawab, empati, dan lain sebagainya, yang berkaitan dengan teori para ahli tentang kepemimpinan.Ini adalah lebih baik jika pemimpin madrasah berasal dari generasi yang mempunyai sifat kepribadian tawadhu' karena, secara tidak langsung, hal itu mempengaruhi kualitas kepemimpinan di sebuah madrasah. Setelah seseorang menjadi pemimpin di madrasah, ia harus mampu melakukan dengan sangat baik karena itu berarti bahwa ia mempunyai tanggung jawab di dunia dan di akhirat. Rasulullah saw. melihat orang melarang meminta untuk menjadi pemimpin, terutama ketika mereka tidak memiliki aspek kualitas kepemimpinan yang terbaik. Jika orang bersikeras untuk tanggung jawab itu, Allah swt tidak akan memberkati pekerjaan itu, dan selanjutnya, mungkin ada hal-hal buruk terjadi di masa depan, seperti kegagalan siswa dalam ujian nasional, kurangnya prestasi sekolah, kurangnya ketergantungan masyarakat, dan sebagainya sebagainya. Ini mungkin terjadi karena pada dasarnya, Allah swt tidak akan membantu orangorang yang meminta kedudukan semata.

Kata kunci: Pemimpin, Madrasah, Alqur'an, Hadits

\section{Pendahuluan}

Setiap manusia dalam pendangan Islam adalah pemimpin bagi dirinya sendiri, apakah dia bisa mengatur atau memimpin dirinya sendiri ataukah dia melalaikan dirinya sendiri. Ketika seseorang mampu memimpin dirinya sendiri maka ia akan selamat hidupnya di dunia dan di akhirat. Sebaliknya apabila ia tidak bisa memimpin dirinya sendiri maka ia akan terjerumus dalam kemaksiatan dan dosa. Memimpin diri sendiri memiliki makna bahwa ada raja dalam tubuh manusia yang berupa segumpal darah, apabila segumpal darah itu baik maka seluruh tubuh akan baik dan sebaliknya 
apabila segumpal darah itu buruk maka seluruh tubuhnya akan buruk ketahuilah bahwa segumpal darah itu adalah hati. (Al Hasimy tt: 29)

Seorang kepala madrasah merupakan pemimpin dalam lingkungan pendidikan Islam. Pemimpin di madarasah memiliki beberapa tugas penting yang harus dia laksanakan sebagai bentuk tanggung jawab yang harus dia jalankan dalam proses kepemimpinannya. Pada kenyataannya di masyarakat masih ada pemimpin di lembaga pendidikan yang diangkat sebagai kepala madrasah/sekolah dengan cara-cara yang kurang baik, seperti pengangkatan kepala madrasah disebabkan karena ada unsur nepotisme, suap, dan kepentingankepentingan lain yang tidak di benarkan dalam ajaran Islam.

Dalam pembahasan pemimpin madrasah kali ini, akan dibahas bagaimana sesungguhnya seorang pemimpin itu diangkat dan diamanahi beberapa tugas dalam dunia pendidikan. Pengangkatan seorang pemimpin sesungguhnya di dasarkan pada dedikasinya atau prestasinya dalam mengembangkan lembaga pendidikan Islam sehingga dianggap mampu untuk diberi amanah memimpin lembaga pendidikan Islam dalam hal ini adalah madrasah.

\section{Pembahasan}

Pembahasan terkait pemimpin madrasah (kepala madrasah) dalam perspektif Al-qur'an dan Hadits ini, tidak melepaskan diri dengan pembahasan pemimpin secara umum dengan menggunakan berbagai teori dan definisi dari para ahli yang berasal dari luar Islam.Pembahasan ini diharapkan untuk memperoleh pengetahuan tentang pemimpin secara komprehenship. Berikut beberapa definisi pemimpin, syarat pemimpin yang baik, teori munculnya pemimpin, macam-macam pemimpin dan lain sebagainya yang terkait dengan kepemimpinan.

\section{Definisi Pemimpin}

Ada beberapa definisi tentang pemimpin yang dibahas oleh para ahli diantaranya:

1) Stephen P. Robbins (1988:370), mengatakan bahwa pemimpin adalah orang yang mampu mempengaruhi orang lain.

2) Ahmad Rusli menyatakan pemimpin adalah individu manusia yang diamanahkan memimpin subordinat (pengikutnya) ke arah mencapai matlamat yang ditetapkan (Aynul;2009).

3) Kartini Kartono $(1982 ; 12)$ mengatakan pemimpin adalah seorang pribadi yang memiliki kecakapan dan kelebihan khususnya kecakapan dan kelebihan disatu bidang, sehingga dia mampu mempengaruhi orangorang lain untuk bersama-sama melakukan aktivitas-aktivitas tertentu, demi pencapaian satu atau beberapa tujuan.

4) pemimpin menurut Suradinata (1997:11) adalah orang yang memimpin kelompok dua orang atau lebih, baik organisasi maupun keluarga

Beberapa pengertian pemimpin di atas memberi makna bahwa pemimpin adalah orang yang memiliki beberapa kecakapan dan kelebihan khusus sehingga mampu mempengaruhi, menggerakkan dan mengarahkan orang untuk melakukan aktivitas demi mencapai beberapa tujuan dari organisasi yang di pimpinnya.

2. Syarat menjadi Pemimpin yang baik 
Kepala madrasah merupakan seorang pemimpin dalam dunia pendidikan. Ada beberapa pengertian pemimpin diantaranya:

a) Menurut Stodgill dalam bukunya "Personal Factors associated with leadership" yang dikutip oleh james A.Lee dalam bukunya "Management Theories and Prescriptions" menyatakan bahwa pemimpin itu harus memiliki beberapa kelebihan yaitu:
1) Kapasitas: Kecerdasan, kewaspadaan, kemampuan berbicara atau verbal vasiliti, keaslian, kemampuan menilai.

2) Prestasi (achievement): gelar kesarjanaan, Ilmu pengetahuan, perolehan dalam olah raga dan atletik dan lain-lain.

3) Tanggung jawab; mandiri, berinisiatif, tekun, ulet, percaya diri, agresif dan hastrat untuk unggul.

4) Partisipasi: aktif, memiliki sosiabilitas tinggi, mampu bergaul, kooperatif atau suka bekerjasama, mudah menyesuaikan diri, punya rasa humor.

5) Status: mempunyai kedudukan social ekonomi cukup tinggi, popular, tenar (Kartono, 1982;31)

b) Menurut Earl Nightingale dan Whitt Shult dalam bukunya "Creative Thingking - how to win Ideas, 1965) dalam (Kartono; 1982:32) menuliskan kemampuan memimpin (yang harus mereka miliki) yaitu:

1) Kemandirian, berhasrat memajukan diri sendiri

2) Besar rasa ingin tahu dan cepat tertarik pada manusia dan benda-benda (curios)
3) Multi Trampil atau memiliki ketrampilan beraneka ragam

4) Memiliki rasa humor, enthusiasm tinggi, suka berkawan

5) Perfeksionis, selalu ingin mendapatkan yang sempurna

6) Mudah menyesuaikan diri, adaptasinya tinggi

7) Sabar namun tidak berhenti.

8) Waspada peka, jujur, optimis, berani, gigih, ulet, realistis.

9) Komunikatif, serta pandai berbicara atau berpidato

10) Berjiwa wiraswasta

11) Sehat jasmaninya, dinamis sanggup dan suka menerima tugas yang berat, serta berani mengambil resiko

12) Tajam firasatnya dan adil pertimbangannya.

13) Berpengetahuan luas dan haus akan ilmu pengetahuan

14) Memiliki motivasi yang tinggi dan menyadari target atau tujuan hidupnya yang ingin dicapai, dibimbing oleh idealism yang tinggi

15) Punya imaginasi yang tinggi daya kombinasi dan daya inovasi.

Beberapa syarat menjadi pemimpin yang baik, sebagaimana yang tersebut di atas merupakan hal yang secara mutlak harus dimiliki oleh seorang pemimpin.Walaupun pada kenyataannya memperoleh pemimpin yang baik dengan syarat tersebut di atas bukanlah suatu hal yang mudah di dapat. Akan tetapi upaya mencari pemimpin tersebut akan menjadi lebih baik apabila persyatatan tersebut dapat terpenuhi minimal mendekati.

\section{Teori Munculnya Seorang Pemimpin}


Seorang kepala madrasah dipilih dan diamanahi dengan jebatan pemimpin lembaga pendidikan sesungguhnya dikarenakan ia memiliki beberapa kelebihan dan kecakapan. Untuk menjelaskan munculnya seorang pemimpin secara umum ada tiga teori yang menjelaskan munculnya seorang pemimpin, (Kartono, 1982:29) yaitu: 1). Teori Genetis, 2) Teori Sosial, dan 3). Teori Ekologis.

1) Teori Genetis menyatakan sebagai berikut: Pemimpin itu tidak di buat, akan tetapi lahir jadi pemimpin oleh bakat-bakatnya yang lauar biasa sejak lahir. Dia ditakdirkan lahir jadi pemimpin, dalam situasi kondisi yang bagaimanapun juga. Secara filosofi teori tersebut menganut pandangan yang deterministic dan fatalistis

2) Teori Sosial (lawan teori genetis) menyatakan sebagai berikut:Pemimpin-pemimpin itu harus di siapkan dan di bentuk, tidak dilahirkan saja. Setiap orang bisa menjadi pemimpin, melalui usaha penyiapan dan pendidikan

3) Teori ekologis/Synthetis (muncul dari rekasi dari kedua teori tersebut) menyatakan sebagai berikut:Seseorang akan sukses menjadi pemimpin, bila sejak lahirnya dia telah memiliki bakatbakat kepemimpinan, dan bakatbakat ini sempat dikembangkan melalui pengalaman dan usaha pendidikan juga sesuia dengan tuntutan lingkungan / ekologisnya.

$$
\text { Ketiga teori munculnya }
$$
pemimpin ini merupakan gejala yang diamati oleh para pakar terkait tentang munculnya seorang pemimpin sepertiteori genetik, biasanya teori ini muncul dilihat dari fenomena negara kerajaan. Putra dari sangraja memiliki hak penuh untuk di nobatkan sebagai putra mahkota yang nantinya akan menggantikan ayahnya sebagai pemimpin. Sedangkan teori social muncul akaibat dari fenomena negara yang menggunakan asas demokrasi. Setiap warga negara berhak untuk menjad seorang pemimpin dengan cara memiliki ilmu pengetahuan yang luas dan kemampuan memimpin sebuah organisasi. Berbeda dengan ekologis yang merupakan gabungan dari kedua teori sebelumnya yang menganggap bahwa pemimpin akan lebih baik jika memiliki keturunan yang baik dan memiliki pendidikan kepemimpinan yang baik pula.

\section{Macam-macam Pemimpin}

Pemimpin dilihat dari perspektif macam-macamnya ada dua. Pemimpin formal dan informal. Menurut Winardi (1990:32) bahwa pemimpin terdiri dari pemimpin formal (formal leader) dan pemimpin informal (informal leader). Pemimpin formal diangkat dan diberhentikan sesuai dengan surat keputusan yang di buat oleh lembaga tertinggi yang terdiri dari beberapa orang. Biasanya pemimpin formal memegang jabatannya dalam kurun waktu tertentu. Pemimpin formal ini berada pada instansiinstansi pemerintah dan juga swasta yang memiliki legalitas keberadaan organisasinya.

Pemimpin informal biasanya terdapat pada masyarakat yang diangkat karena memiliki beberapa kelebihan. Seperti pemimpin jamaah sholat, tahlil, yasin paguyuban dan lain-lain. Pemimpin informal ini biasanya diangkat dan diberhentikan sewaktu waktu sesuai dengan keinginan masyarakat itu sendiri dan bahkan tidak pernah diganti seumur hidup.

\section{Sifat-Sifat Pemimpin pada Lembaga Pendidikan Islam}


Dalam memimpin lembaga pendidikan seorang kepala madrasah harus memiliki kemampuan yang lebih, baik kemampuan yang terdapat dalam dirinya sendiri maupun kemampuan dalam mengatur orang lain secara adil. Ada beberapa sifatsifat yang harus dimiliki oleh seorang pemimpin. Minimal ada beberapa unsur sifat-sifat pemimpin yang dimiliki oleh Nabi Muhammad saw.yang harus diteladani dari sekian banyak sifat Nabi dalam hubungannya dengan pemimpin dalam lembaga pendidikan Islam. Sifat-sifat tersebut akan sangat membantu bagi perkembagan pendidikan Islam dari perspektif kemampuan seorang kepala madrasah dalam dalam mengelola lembaga pendidikannya.

Menurut Nawwal AthThuwairaqi (2004), Diantara tiga belas sifat yang harus dimiliki antara lain: (1) Prinsip kesabaran,(2) Prinsip tawadhu, (3)Prinsip kejelasan dan kerjasama, (4) Prinsip pemaaf,(5) Prinsip tegas, (6) Prinsip keadilan, (7) Prinsip saling menasehati, (8) Prinsip memotivasi,(9) Prinsip tolong menolong,(10) Prinsip mengutamakan kepentingan umum, (11) Prinsip menepati janji,(12) Prinsip berbicara sesuai taraf berfikir lawan,(13) Prinsip pernuh perhatian pada orang lain.Semua prinsip-prinsip di atas merupakan sebagian prilaku-prilaku yang di lakukan oleh Nabi Muhammad Saw. dalam mengemban dan menyebarkan dakwah Islamiyyah pada kaum kafir Quraisy. Dengan prinsip yang mulia, akhirnya beliau berhasil mengembangkan dan menyebarkan dakwah Islamiyyah pada orang orang kafir, yang selama ini memusuhi, mencaci maki dan berusaha membunuh Belaiu agar dakwahnya berhenti.

Berikut ini ada beberapa contoh prilaku yang di lakukan oleh nabi yang dikutip dari Buku Nawwal AthThuwairaqi (2004:45), yang menceritakan tentang banyak hal yang menyangkut prilaku ahlak Nabi Muhammadsaw. Prinsip-prinsip itu diantaranya:

1) Prinsip Kesabaran

Seorang pemimpin di lembaga pendidikan hendaknya memiliki sifat penyabar kepada bawahan dan anak didiknya, seperti Rasulullah saw. saw sangat lembut dengan para sahabat bahkan dengan para musuhnya. Beliau tidak pernah marah, kecuali jika terjadi pengabaian dalam penegakan hukum-hukum Allah Swt. atau tindakan buruk kapada agama Islam.Jika tindakan buruk itu menganiaya dirinya, maka Beliau tidak marah. Banyak kejadian yang menunjukkan kesabaran Rasulullah saw. dalam menghadapi rintangan penyebaran ajaran Islam seperti ketika Rasulullah saw. ingin melaksanakan umrah pada tahun 6 hijriyah. Setelah mengirimkan mata-mata beliau maka disampaikannya kepada Rasulullah saw. bahwa kaum Quraisy bertekat untuk mengusir beliau dari Masjidil Haram dan kaum muslimin dilarang masuk kota Makkah bahkan akan di serang oleh Ka'ab bin Lu'ay agar tidak masuk ke Makkah. Maka setiba Beliau di Hudaibiyyah diadakanlah perjanjian yang di kenal dengan perjanjian Hudaibiyah yaitu dengan syarat bahwa Rasullullah saw.tidak boleh masuk Makkah tahun ini. Kemudian dibuatlah perjanjian itu dengan banyak merugikan kaum Muslimin, akan tetapi Rasulullah saw. menyetujuinya. 
Kesabaran yang muncul dalam diri Rasulullah saw. berdasarkan wahyu sesuai dengan firman Allah swt dalam QS. Al Baqorah ayat 102

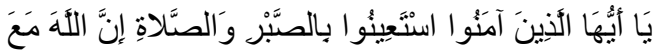

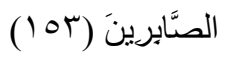

Hai orang-orang yang beriman, Jadikanlah sabar dan shalat sebagai penolongmu, Sesungguhnya Allah beserta orang-orang yang sabar.

2) Prinsip Tawadhu

Seorang pemimpin di lembaga pendidikan hendaknya memiliki sifat tawadhu' kepada bawahan dan anak didiknya seperti Rasulullah saw. bertawadhu' hingga jika Beliau berjalan di sekitar anak-anak yang sedang bermain, Beliau akan tersenyum dan ikut bergabung. Rasulullah saw. sangat bertawadhu' kepada yang lebih muda apalagi kepada yang lebih tua. Seperti yang diriwayatkan oleh Al Jazairi, Abu Bakar beserta ayahnya datang menghadap Rasulullah saw. pada Fathu Makkah, ketika Rasulullah saw. mengetahui hal itu, maka Rasulullah saw. bersabda kepada Abu Bakar, bagaimana jika syeh (ayah Abu Bakar) tinggal aja di rumah sehingga aku yang datang kepadanya?. Abu Bakar berkata wahai Rasulullah saw. ia lebih berhak datang kepada engkau dari pada engkau yang harus datang kepadanya. Allah swt berfirman dalam QS. Al Furqan ayat 63

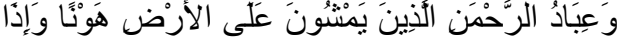

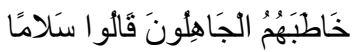

"Dan hamba-hamba Tuhan yang Maha Penyayang itu (ialah) orang-orang yang berjalan di atas bumi dengan rendah hati dan apabila orang-orang jahil menyapa mereka, mereka mengucapkan kata-kata (yang mengandung) keselamatan."

3) Prinsip Kejelasan dan Kerja Sama
Seorang pemimpin di lembaga pendidikan hendaknya juga memiliki sifat kejelasan dan kerjasama antara satu lembaga dengan lembaga lain demi memajukan lembaga pendidikannya, seperti Ketika Rasulullah saw. pergi melaksanakan umrah ke Makkah dan kaum Quraisy melarang beliau masuk ke Masjidil Haram dengan alasan karena beliau di anggap akan menyerang mereka. Rasulullah saw. harus menjelaskan kepada mereka, bahwa beliau ke Makkah untuk melaksanakan Umrah bukan untuk menyerang orang.

Kemudian Rasulullah saw. menjelaskan kepada Badil bahwa peperangan telah menghancurkan kaum Quraisy. Jika mereka membiarkan saja hubungan antara orang-orang Qurais dengan kaum Muslimin apa adanya, sehingga siapa saja yang mau masuk Islam, di bebaskan, akan tetapi jika mereka menginginkan peperangan, maka Rasulullah saw. siap untuk memerangi mereka demi dakwah sekalipun beliau harus terbunuh atau Allah akan melaksanakan urusan-Nya. maka tidak ada pilihan bagi Badil kecuali dirinya harus pulang dan menjelaskan kepada kaum Quraisy pembicaraan apa yang terjadi antara dirinya dan Rasulullah saw.

Dengan sikap kejelasan dan kerjasama tersebut di atas, Rasulullah saw. mampu menarik kepercayaan orang-orang sekitar beliau. Sikap kerjasama tersebut juga mampu memunculkan rasa cinta, rasa kedekatan mereka kepada beliau, dan mampu membuat mereka mati-matian dalam bekerja dan ikhlas di dalam dakwah Islamiyyah. Apabila merujuk pada tugas kepala sekolah (madrasah), maka kepala madrasah tidak hanya 
dituntut untuk menjalankan berbagai tugas di sekolah dengan jelas, tetapi ia juga harus mampu menjalin hubungan kerjasama dengan masyarakat guna membina peserta didik secara optimal, (Mulyasa: 2005: 186).

4) Prinsip Pemaaf

Rasulullah saw. telah mengamalkan prinsip ini dalam setiap interaksinya dengan para sahabat dan dengan musuh-musuhnya. Seperti ketika Rasulullah saw. pergi bersama 1000 prajurit, dan orang-orang mukmin melewati tombak milik Marba' bin Qaidzi (orang Munafik) ketika mendengar bahwa Rasulullah saw. dan kaum Muslimin akan lewat ia menolaknya seraya mengambil debu dengan dua tangannya dan berkata, demi Allah jika aku menghetahui bahwa debu ini bisa tidak mengenai selain engkau wahai Muhammad, tentu aku pukul wajahmu dengannya. seketika majulah Sa'ad bin Zaid untuk membunuhnya dengan sabetan pedang hingga melukai kepalanya dan di ikuti oleh orang-orang banyak. Rasulullah saw. berkata kepada mereka Biarkan dia jangan kalian bunuh kerena hati dan matanya buta. Masih banyak lagi contoh-contoh yang menunjukika sikap pemaaf dari Rasulullah saw. baik terhadap para sahabatnya maupun terhadap para musuh-musuhnya. Allah swt berfirman dalam QS. Al A'raf ayat 199

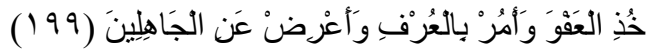
Jadilah Engkau Pema'af dan suruhlah orang mengerjakan yang ma'ruf, serta berpalinglah dari pada orang-orang yang bodoh.

5) Prinsip Tegas

Ketegasan Rasulullah saw. terlihat ketika pulang dari Hamra Al Asad menuju Madinah membawa serta Abu Izzah, mantan seorang tawanan dari perang Badar yang telah mendapat ampunan dari Rasulullah saw. Akan tetapi ia berkhianat dengan menggerakkan masa melalui syairnya untuk menyerang Rasulullah saw. dan Kaum muslimin, ia keluar untuk bergabung dalam perang Uhud. Ketika ia di tangkap oleh Rasulullah saw. Ia berkata Hai Muhammad lepaskan aku. Berikan keringanan untukku, biarkan aku mengurus anak-anak perempuanku, aku berjanji tidak akan mengulanginya lagi. Rasulullah saw. bersabda jangan kamu tutupi para pendukungmu di Mekkah setelah ini. Lalu ia mengatakan engkau telah menipu Muhammad dua kali Beliau telah memerintahkan Al-Zubair untuk melakukan pemenggalan terhadap leher Abu Izzah.

6) Prinsip Keadilan

Keadilan yang ditunjukkan oleh Rasulullah saw. Sebagaimana di tulis Al Jazairi bahwa: dalam perang Badar Rasulullah saw. mulai meluruskan barisan para sahabat. ditangan beliau terdapat wadah anak panah yang beliau gunakan untuk meluruskan barisan para sahabat. Ketika Beliau lewat di dekat Sawwad Bin Aziyyah yang kelihatan tidak meluruskan barisan dan menonjol dari shaf. Rasulullah saw. memukul perutnya seraya berkata: "Lurus kan wahai Sawwad"! Sawwad menjawab: "Wahai Rasulullah saw. Engkau telah menyakitiku, padahal Engkau telah di utus oleh Allah Swt. dengan kebenaran dan keadilan".Berikan padaku membalas padamu. Rasulullah saw. membuka bajunya seraya bersabda:"lakukan pembalasan"! Sawwad langsung memeluk perut Rasulullah saw. dan menciumnya, Rasulullah saw. bersabda: "apa yang membuatmu demikian wahai 
Sawwad"? Sawwad menjawab: "apa yang Engkau lihat karena saya berkeinginan agar akhir pertemuanku dengan Engkau adalah sentuhan antara kulitku dengan kulit Engkau." Sifat keadilan beliau merupakan contoh seorang pemimpin yang baik sebagaimana firman Allah dalam QS. An-Nahl Ayat 90

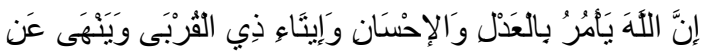

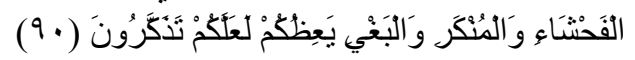

Sesungguhnya Allah menyuruh (kamu) Berlaku adil dan berbuat kebajikan, memberi kepada kaum kerabat, dan Allah melarang dari perbuatan keji, kemungkaran dan permusuhan.Dia memberi pengajaran kepadamu agar kamu dapat mengambil pelajaran.

7) Prinsip Saling Menasehati

Rasulullah saw. selalu memberi nasehat dan menerina masehat dari orang lain. Salah satunya disebutkan oleh Al Jazairi ketika terjadi Fathu Makkah Rasulullah saw. berjalan hingga di Dza Thawa. Beliau berhenti dengan tetap duduk di atas binatang tungganggannya dengan melipat surbannya beliau membagi pasukan dengan memerintahkan Zubair Bin Al Awwam agar datang kepada orang-orang di Kadi.Sementara beliau memerintahkan Sa'ad bin Ubaddah agar datang kepada orangorang di Kada' di tanah yang tinggi di dengar bahwa Sa'ad berkata kepada orang-orang, "hari ini adalah hari pesta hari ini di halalkan sesuatu yang dilarang".kemudian Umar Bin Khottab bertkata Wahai Rasulullah saw. aku mendengar apa yang dikatakan oleh Sa'ad Bin Ubbaddah Sehingga kami merasa tidak aman jika ia sampai di kuasai oleh orang-orang Quraisy. Rasulullah saw. berkata kepada Ali Bin Abi Tholib temui dia dan ambil panji dari tangannya dan engkaulah yang masuk pada orang-orang itu.

Allah swt berfirman dalam QS. Al-Asr ayat 3:

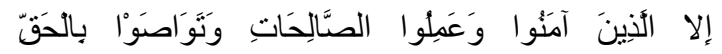

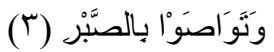

.... kecuali orang-orang yang

beriman dan mengerjakan amal saleh dan nasehat menasehati supaya mentaati kebenaran dan nasehat menasehati supaya menetapi kesabaran.

8) Prinsip Memotivasi

Rasulullah saw. Membangkitkan para sahabatnya untuk angkat senjata dalam perang Uhud dan agar bersabar serta tegar ketika perang mulai berkobar. Ditengah-tengah ucapan itu, Beliau menghunus sebilah pedang yang sangat tajam seraya berseru ditengah-tengah barisan para sahabat, "Siapa yang siap mengambil pedang ini dan memenuhi haknya"? Kemudian banyak orang yang bangkit untuk mengambil pedang itu dari Rasulullah saw.. Diantara mereka terdapat Ali Bin Abu Tholib, Umar bin Khottab, dan Azzubair Bin Al Awwam. Dari mereka yang bangkit dan dekat Rasulullah saw.adalah Abu Dajanah Sammak Bin Kharrasyah. Ia berkata apa hak pedang itu wahai Rasulullah saw.? Beliau menjawab: Haknya adalah engkau memenggal leher musuh dengannya hingga tewas Abu Dajanah berkata aku akan mengambilnya untuk memenuhi haknya. Selanjutnya Rasulullah saw. memberikan pedang tersebut kepada Abu Dajanah.

Allah swt berfirman dalam QS. Az Zumar ayat 53:

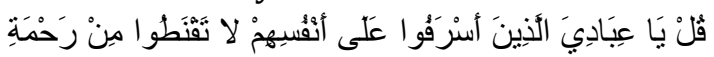

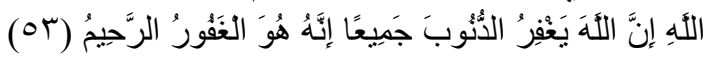


Katakanlah: "Hai hambahamba-Ku yang malampaui batas terhadap diri mereka sendiri, janganlah kamu berputus asa dari rahmat Allah. Sesungguhnya Allah mengampuni dosa-dosa semuanya.Sesungguhnya Dia-lah yang Maha Pengampun lagi Maha Penyayang.

9) Prinsip Tolong Menolong

Rasulullah saw. adalah sosok manusia yang suka menolong orang yang sedang dalam kesusahan, apalagi menolong saudaranya muslim. Allah swt berfirman dalam QS. Al Maidah ayat 2:



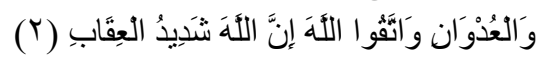
...dan tolong-menolonglah kamu dalam (mengerjakan) kebajikan dan takwa, dan jangan tolongmenolong dalam berbuat dosa dan pelanggaran. dan bertakwalah kamu kepada Allah, Sesungguhnya Allah Amat berat siksa-Nya.

Sifat ini terlihat ketika kaum muslimin bersepakat untuk menggali parit pada perang Ahzab.mereka memulai pekerjaan itu dan Rasulullah saw. juga turut menggali bersama mereka serta melakukan pembagitan tugas penggalian. Setiap 10 orang diberi amanah untuk menggali sepanjang 40 hasta.Semua orang sibuk dengan penggalian sebagian sibuk menggali dan sebagian sibuk memindahkan dan menjauhkan tanah galian.

10) Prinsip Mengutamakan Kepentingan Umum

Mementingkan kepentingan umum sangat jelas dilakukan oleh Rasulullah saw. ketika beliau mengadakan perjanjian dengan Ghothofan yaitu: kaum muslimin mendapatkan hak sepertiga dari hasil buah-buahan di Madinah.Hal ini dilakukan karena dirasa oleh Beliau begitu beratnya kondisi akibat pengepungan kaum musrikin terhadap kaum muslimin pada perang Khandaq. Apalagi ketika musuh-musuh bersepakat bulat menyerang kaum muslimin sehingga kondisi kaum muslimin bertambah sangat sempit dan sulit. Tujuan Rasulullah saw. berdamai dengan Ghathafan dengan mendapatkan hak sepertiga buahbuahan agar Ghathafan pulang bersama musuh-musuh Islam yang lain dan tidak menyerang kaum Muslimin Madinah. Ini tiada lain merupakan keinginan Rasulullah saw. untuk mempertahankan keadaan kaum Muslimin setelah melihat keadaan musuh.

11) Prinsip Menepati Janji

Dengan prinsip ini Rasulullah saw. selalu berhasil menarik kepercayaan kawan dan lawan. Seperti dalam sejarah tercatat bahwa dalam perjanjian Hudaibiyyah Rasulullah saw. dan para sahabat meninggalkan Makkah pada tahun itu serta membatalkan rencananya untuk berumrah. Beliau dan para sahabatnya di beri waktu sampai 3 hari pada tahun berikutnya untuk melaksanakan umrah lalu kembali ke Madinah dengan jaminan kemaanan dan ketemtraman beribadah. Dan setelah beliau melakukan umrah kaum Quraisy mengutus Khuwaithiba Bin Abdul Izzi dengan beberapa orang lainnya untuk menghadap Rasulullah saw. Guna meminta agar beliau dan para sahabatnya untuk meninggalkan kota Makkah pada akhir hari itu juga dalam rangka menepati kesepakatan. Maka Rasulullah saw. meninggalkan Makkah setelah habis masa tinggalnya. 
Allah swt berfirman dalam QS. Al Fath Ayat 10

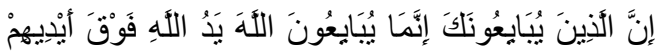

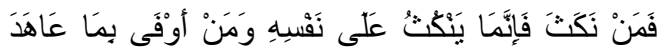

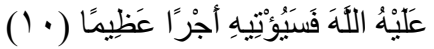

Bahwasanya orang-orang yang berjanji setia kepada kamu Sesungguhnya mereka berjanji setia kepada Allah.tangan Allah di atas tangan mereka, Maka Barangsiapa yang melanggar janjinya niscaya akibat ia melanggar janji itu akan menimpa dirinya sendiri dan Barangsiapa menepati janjinya kepada Allah Maka Allah akan memberinya pahala yang besar.

12) Prinsip Berbicara Sesuai Taraf Berfikir Lawan

Adi bin Hatim ketika menghadap kepada Rasulullah saw. dirumahnya setelah duduk, Rasululllah bersandar Hai Adi Bin Hatim, bukankah engkau seorang yang melakukan dosa? Ia menjawab ya. Lalu Rasulullah saw. bertanya bukankah engkau telah berlalu di depan kaummu dengan membawa seperempat Ghonimah? ia menjawab ya. Lalu beliau bersabda semua itu tidak halal bagimu menurut agamamu.Ia menjawab demi Allah itu benar. Adi Bin Hatim berkata aku mengetahui ia adalah seorang Nabi yang telah di utus untuk menjelaskan apa-apa yang tidak di ketahui.

13) Prinsip Penuh Perhatian Pada Orang Lain

Dalam perang Ahzab ketika orang-orang arab dengan terangterangan memusuhi kaum muslimin sementara kaum Yahuda dari Bani Quraidhah membatalkan perjanjian damai antara mereka dengan Rasulullah saw. dengan memberikan bantuan kepada tentara kaum musrikin dalam serangan mereka kepada kaum muslimin. Tetapi Rasulullah saw. tidak mau menghadapi secara militer kalau perkaranya belum jelas.Untuk mencari kejelasan itu Rasulullah saw. mengutus orang untuk menyelidiki keadaan dengan sangat rahasia agar tidak menjatuhkan mental dan menimbulkan perasaan takut dalam hati mereka. Setelah mengetahui intel dari tentara kaum muslimin. Kemudian beliau memerintahkan kepada para utusannya untuk memperjelas permasalahan jika kaum yahudi itu masih memelihara perjanjiannya dengan Rasulullah saw., maka mereka boleh mengumumkan kepada kaum muslimin bahwa kaum Yahudi masih memelihara perjanjian mereka dengan Rasulullah saw. sehingga tidak hilang kepercayaan diri dan semangat mereka. Akan tetapi jika benar kaum Yahudi Madinah mengingkari janji mereka dengan Rasulullah saw. maka utusan itu tidak boleh mengumumkan terang-terangan tentang berita tersebut. Namun cukup dengan memberikan sinyal kepada Rasulullah saw. bahwa mereka telah ingkar janji.

\section{Elaborasi Teori}

Seorang pemimpin dalam definisi teori adalah seorang pribadi yang memiliki kecakapan dan kelebihan khususnya kecakapan dan kelebihan disatu bidang, sehingga dia mampu mempengaruhi orang-orang lain untuk bersama-sama melakukan aktivitasaktivitas tertentu, demi pencapaian satu atau beberapa tujuan.Definisi tersebut menunjukkan bahwa seorang pemimpin / kepala madrasah harus memiliki kecakapan dan kelebihan dalam melakukan aktivitas-aktivitas dalam lembaga pendidikannya.Sehingga ada beberapa syarat yang harus dimiliki oleh seorang kepala madrasah agar dapat 
menjalankan aktifitas kepemimpinannya. Syarat tersebut diantaranya:

Menurut Stodgill dalam bukunya

"Personal Factors associated with leadership" yang dikutip oleh James A.Lee dalam bukunya "Management Theories and Prescriptions" menyatakan bahwa pemimpin itu harus memiliki beberapa kelebihan yaitu: 1) Kapasitas: Kecerdasan, kewaspadaan, kemampuan berbicara atau verbal vasiliti, keaslian, kemampuan menilai. 2). Prestasi (achievement): gelar kesarjanaan, Ilmu pengetahuan, perolehan dalam olah raga dan atletik dan lain-lain. 3). Tanggung jawab; mandiri, berinisiatif, tekun, ulet, percaya diri, agresif dan hastrat untuk unggul.4). Partisipasi: aktif, memiliki sosiabilitas tinggi, mampu bergaul, kooperatif atau suka bekerjasama, mudah menyesuaikan diri, punya rasa humor. 5). Status: mempunyai kedudukan sosial ekonomi cukup tinggi, popular, tenar (Riadi; 2012)

Berbagai persyaratan pemimpin di atas sungguh sangat berat menjadi seorang pemimpin.Ia harus memiliki semua kecakapan dan kemampuan tersebut. Dalam Islam-pun para sahabat Rasulullah saw. tidak meminta jabatan akan tetapi mereka ditunjuk berdasarkan beberapa pertimbangan yang banyak dan sangat matang seperti: Abubakar Assiddiq, Umar Bin Khottob, Usman Bin Affan dan Ali Bin Abi Tholib walaupun ada beberapa permasalahan politik saat itu.

$$
\text { Jabatan menjadi seorang }
$$
pemimpin memang berat tanggungjawabnya. Baik tanggungjawab di dunia maupun tanggungjawab di akhirat. Dalam sejarah di ceritakan bahwa sahabat Abi Dzar al Ghifari yaitu salah satu sahabat yang sangat dekat dengan Rasulullah saw. saw bahkan di sayangi beliau. Sehingga begitu dekatnya sampai Abu Dzar dengan Rasulullah saw. saw, disuatu hari pernah Abu Dzar meminta jabatan kepada
Rasulullah saw. Maka beliau langsung menasehatinya.

Rasulullah saw. saw bersabda:

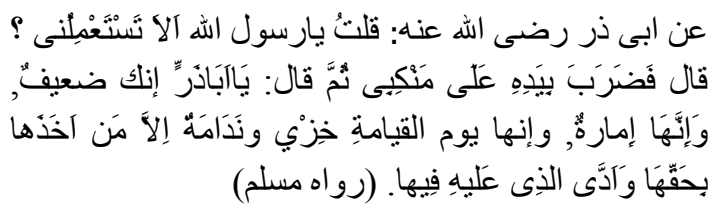
Sahabat Abi Dzar ra.Berkata : Aku pernah berkata Kepada Rasulullah saw. “ Ya Rasulallah mengapa aku tidak engkau beri jabatan"? lalu Rasulullah saw. memukul-mukul pundakku dengan telapak tangan seraya bersabda: Ya Abu Dzar engkau adalah lemah. Sedang menjadi pemimpin itu berat, dan kelak pada hari kiamat akan menyesal lagi hina, kecuali orang yang melaksanakan kepemimpinannya dengan baik lagi adil. (HR Muslim).

Dalam hadits lain Rasulullah saw. bersabda:

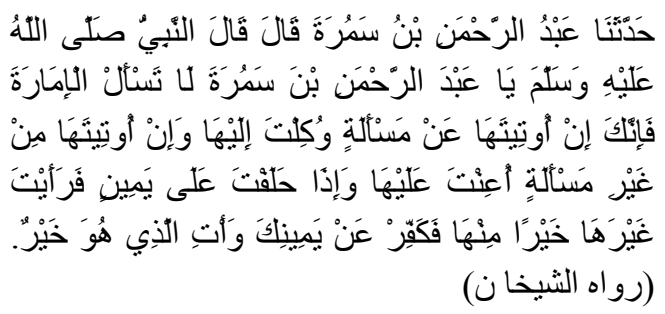

Dari Abdurrahman ibn Samurah ra. Ia berkata : Rasulullah saw. bersabda :"Wahai Abdurrahman Ibn sammurah, janganlah kamu meminta jabatan. Jika kau diberi jabatan karena memintanya, jabatan itu diserahkan sepenuhnya. Dan Apabila kamu diberi dan tidak memintanya, kamu akan mendapat pertolongan Allah dalam melaksanakannya. Apabila kamu bersumpah terhadap satu perbuatan, kemudian kamu melihat ada perbuatan yang lebih baik, maka kerjakanlah perbuatan yang lebih baik itu." (HR Bukhari dan Muslim)

Hadits tersebut di atas menunjukkan bahwa jika seseorang tidak meminta jabatan maka ia akan diberi 
perolongan oleh Allah dalam menjalankan kewajibannya seperti kalimat:

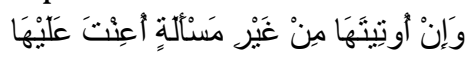

Dan Apabila kamu diberi dan tidak memintanya, kamu akan mendapat pertolongan Allah dalam melaksanakan kepemimpinan. Hal ini sesuai dengan syarah hadits yang mengatakan bahwa "Siapa yang tidak meminta jabatan, Allah akan menolongnya dalam menjalankan tugasnya" dan hadits Imam Bukhori no. 7147 dengan judul "Siapa yang minta jabatan, akan diserahkan padanya (dengan tidak mendapat pertolongan dari Allah dalam menunaikan tugasnya)". Diriwayatkan pula oleh Al-Imam Muslim dalam Shahih-nya no. 1652 yang diberi judul oleh Al-Imam An-Nawawi "Bab Larangan meminta jabatan dan berambisi untuk mendapatkannya”. (dalam Penjelasan Sahih Muslim, jilid 12, halaman 210).

Berkata Syaikh Ibnu Utsaimin rahimahullah: "Seseorang yang meminta jabatan seringnya bertujuan untuk meninggikan dirinya di hadapan manusia, menguasai mereka, memerintahkannya dan melarangnya. Tentunya tujuan yang demikian ini jelek adanya. Maka sebagai balasannya, ia tidak akan mendapatkan bahagiannya di akhirat. Oleh karena itu dilarang seseorang untuk meminta jabatan." (Syarh Riyadlus Shalihin, 2/469) Berkata Al Muhallab sebagaimana dinukilkan dalam Fathul Bari (13/135): "Ambisi untuk memperoleh jabatan kepemimpinan merupakan faktor yang mendorong manusia untuk saling membunuh. Hingga tertumpahlah darah, dirampasnya harta, dihalalkannya kemaluan-kemaluan wanita (yang mana itu semuanya sebenarnya diharamkan oleh Allah) dan karenanya terjadi kerusakan yang besar di permukaan bumi."Allah Swt berfirman dalam QS. Muhammad 22-23:



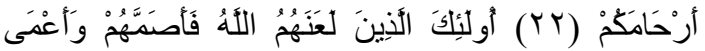



Maka apakah kiranya jika kamu berkuasa kamu akan membuat kerusakan di muka bumi dan memutuskan hubungan kekeluargaan? Mereka Itulah orang-orang yang dilaknati Allah dan ditulikan-Nya telinga mereka dan dibutakan-Nya penglihatan mereka.

Dalam tafsir al Baghowi di sebutkan bahwa:

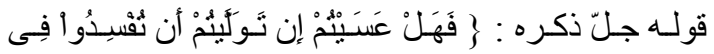

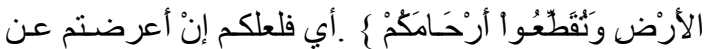

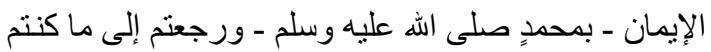

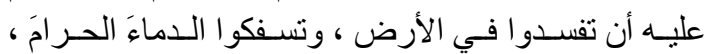

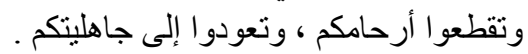

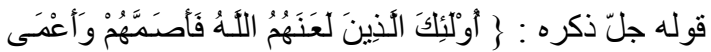

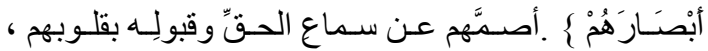
و أعمى بصائرَهم.

Dalam tasir lainAl Bahr Al Muhith VIII/82 Maka, maksud ayat itu adalah, jika kalian (orang-orang munafik) berpaling dari melaksanakan perintah Allah tentang jihad, maka tidaklah ada yang ditunggu dari kalian kecuali kalian akan berbuat kerusakan di muka bumi jika tidak ada pertolongan dari kaum Muslimin. Untuk itu tolonglah mereka, sebab jika kalian tidak menolong mereka, maka kalian telah memutus tali silaturrahim dengan mereka sehingga pantas mendapat laknat Allah. (Lihat: Tafsir Al Bahr Al Muhith VIII/82).

Orang berbuat kedzaliman terkadang karena memiliki kesempatan inilah yang kemudian terkadang jabatan menjadikan orang lupa akan berbuat adil dan bahkan dalam tafsir di atas menjadikan orang memutus tali persaudaraan demi sebuah kepentingan kekuasaan sehingga terdorong berbuat kedzaliman. Memang seorang pemimpin di tuntut untuk berbuat adil dan berbuat adil merupakan perkara yang berat.Hal ini sebagaimana sabda Rasulullah saw. yang diriwayatkan oleh siti Aisyah ra: 


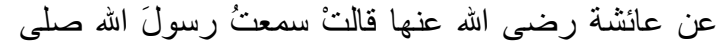

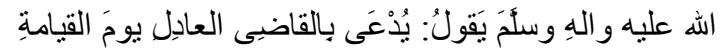


أمرهِ (رواه /بن حبان واخرجه البيهقى ولفظه: في تمرة)

Sahabat Aisyah ra berkata : Aku telah mendengar Rasulullah saw. bersabda: seorang hakim yang adil kelak pada hari kiamat dipanggil menghadap Allah swt. sedangkan dia akan menemukan hukum yang dijatuhkan di pengadilan ketika di dunia sebagai suatu yang benar hanya saja dia akan tetap di hisab dengan hisab yang berat hingga rasanya selama hidup dia tidak ingin memberi hukum kepada dua orang yang bersengketa (HR. Ibnu Hibban dan Baihaqi dengan teks yang berbeda).

\section{Kesimpulan}

Menjadi kepala madrasah dalam Islam haruslah memenuhi berbagai persyaratannya terlebih dahulu. Antara lain:Keadilan, Kejujuran, Ketulusan, rasa tanggungjawab, empati dan lain sebagainya sesuai dengan teori para pakar Ilmu Kepemimpinan yang sangat penting bagi seorang pemimpin.

Kepala madrasah akan lebih baik jika muncul dari keturunan yang baik, sebab keturanan yang baik itu sedikit banyak akan mempengaruhi jiwa pemimpin tersebut. Bukankah junjungan kita Nabi Muhammad saw merupakan pemimpin yang baik dan suci sebab beliau berasal dari keturunan baik dan suci pula (Nabi Ibrahim As).Menjadi pemimpin/kepala madrasah harus siap memikul beban yang berat, sebab ia harus mempertanggungjawabkan kepemimpinannya baik di dunia maupun di akhirat. Rasulullah saw. melarang seseorang minta jabatan, apalagi jika yang bersangkutan memiliki kelemahan-kelemahan sebagai seorang pemimpin.
Hendaklah jabatan tidak di minta, sebab jika diminta maka Allah swt tidak akan menolong kepala madrasah tersebut dan ini mengandung makna akan ada kerusakan - kerusakan dalam kepemimpinannya, bisa berbentuk nilai Ujian Nasional gagal atau tidak lulus, prestasi rendah, kepercayaan masyarakat pada lembaga pendidikan tersebut berkurang dan lain sebagainya, karena pada hakikatnya Allah swt tidak akan menolong orang yang meminta jabatan.

\section{DAFTAR PUSTAKA}

Al Hasyimi ,Ahmad. tt. Muhtarul Ahadits An Nabawiyyah. Surabaya: Darul Ilmu.

Aynul. 2009. Kepemimpinan, http://kepemimpinan-

fisipuh.blogspot.com diakses tanggal 18 Nop 2013

Yukl, Gary.1994. Kepemimpinan dalam Organisasi. Jakarta : Prentice Hall Inc.

Kartono, Kartini.1982. Pemimpin dan kepemimpinan. Bandung: Rajawali Press.

Charles, Keating. 1986. Kepemimpinan Teori dan pengembangannya, Yogyakarta: Kanisius.

Mulyasa, E. 2006.Menjadi Kepala Sekolah Profesional. Bandung: PT Remaja Rosdakarya.

Riadi,Muchlisin. 2012. Pemimpin dan Kepemimpinan (Error! Hyperlink reference not valid.) di akses 2 Juli 2015

Rukmana, Nana. 2007. Etika Kepemimpinan perspektif Agama dan Moral. Bandung: ALVABETA

-13 2013. Ambisi Minta
Jabatan Membawa Kehinaan, diakses
20 Nop 2013
Ghifari ra,Error! Hyperlink


reference not valid.diakses 20 Nop 2013

2006. Khulafaur_Rasyidin, http://id.wikipedia.orgdi akses pada 20 Nov 2013

Robbins, Stephen P.1988 .Management: Concept and Application. new Jersey: Pretice-Hall, Secon Edition

Suradinata, Ermaya.1995. Psikologi Kepegawaian dan Peranan Pimpinan Dalam Motivasi Kerja. Bandung: CV Ramadan.

Sahih Muslim, jilid 12.

Syarh Riyadlus Shalihin, 2/469

Winardi. 1990. Kepemimpinan Dalam Manajemen. Jakarta: PT. Rineka Cipta. 